\title{
The Ability of Pseudomonas sp. SP0113 to Solubilize Tricalcium Phosphate and its Influence on the Development of Spring Wheat
}

\author{
Sebastian Wojciech Przemieniecki*, Tomasz Pawel Kurowski, \\ Karol Kotlarz, Jędrzej Mastalerz \\ Department of Entomology, Phytopathology and Molecular Diagnostics, \\ University of Warmia and Mazury in Olsztyn, Poland
}

Received: 21 November 2017

Accepted: 22 June 2018

\begin{abstract}
Phosphorus is present in soil in various forms, including as insoluble organic compounds. Many species of soil-dwelling microorganisms release phosphorus from compounds that are sparingly soluble and make it partially available to crop plants. This group of microorganisms includes phosphate-solubilizing bacteria (PSB) that release phosphorus from relatively insoluble forms by producing organic acids, mineral acids, siderophores, $\mathrm{CO}_{2}$ and $\mathrm{H}_{2} \mathrm{~S}$. The ability of Pseudomonas sp. SP0113 to solubilize tricalcium phosphate and its influence on the development of spring wheat was determined in this study. Solubilization of tricalcium phosphate (TCP) was evaluated based on changes in the $\mathrm{pH}$ of the NBRIP (National Botanical Research Institute's) phosphate growth medium. $\mathrm{pH}$ and redox potential were measured immediately after the addition of TCP and every 24 hours. Pseudomonas sp. SP0113 proliferated in culture media with $\mathrm{pH}$ lower than 7 , which indicates that the evaluated strain can be used as plant-growth promoting bacteria (PGPB) in acidic soils. Seed dressing improved the biometric parameters of spring wheat. The applied bacterial strain was capable of solubilizing phosphates. Spring wheat treated with Pseudomonas sp. SP0113 was characterized by higher thousand grain weight, kernel yield higher by $7.5 \%$, longer spikes and stems, and a lower dry matter content in comparison with control.
\end{abstract}

Keywords: Pseudomonas sp.; PSB; phosphate solubilizing bacteria; spring wheat

\section{Introduction}

Phosphorus, an essential element for the growth and development of all plants, determines the yield and

*e-mail: microbiology@wp.pl quality of crops [1]. In plants, phosphorus is present as membrane phospholipids, nucleic acids and nucleotides [2]. The phosphorus content of plants ranges $0.1-1.0 \%$ DM, and symptoms of phosphorus deficiency are observed below $0.1 \%$ DM. Phosphorus concentrations are highest in young plants, and they decrease in vegetative organs with age. The discussed element plays 
a very important role in plants, and it determines the growth rate of the root system [3]. Some plant attributes are associated with phosphorus nutrition, for example seed and flower formation, enzyme activity, crop quality, root development and resistance to plant pathogens. Phosphorus is involved in key plant functions, including photosynthesis, energy transfer and transformation of sugars and starches [1, 4].

In arable soils, phosphorus is present in the form of: organic and mineral compounds in the soil solution, precipitated and sparingly soluble mineral compounds, non-specifically adsorbed compounds that are weakly associated with the solid soil fraction, compounds strongly adsorbed by iron, calcium and aluminum oxide-hydroxides, compounds adsorbed by clay minerals, and insoluble organic compounds [2, 5]. The phosphorus content in soils depends on soil type and ranges 0,002-0,12 DM [1,7]. The availability of phosphorus for plants is determined mainly by soil $\mathrm{pH}$. In soils with low $\mathrm{pH}$, phosphorus is more readily adsorbed by hydrated iron and aluminum oxides. Soils with a $\mathrm{pH}$ of 6-7 are characterized by relatively high concentrations of phosphate anions due to reduced phosphorus binding. Phosphorus fertilization produces the best results in soils with a controlled $\mathrm{pH}$ [6].

Microorganisms assimilate soluble phosphorus, preventing it from fixation or adsorption [8]. Fungi are less effective at phosphorous solubilization than bacteria [9]. Microorganisms with the ability to solubilize phosphates in soil increase the amount of available phosphorus for plants and affect positively on plant growth. Inoculation of phosphate-solubilizing bacteriacontaining biofertilizers is beneficial to the yield of many plants $[4,10,11]$.

Various species of soil-dwelling microorganisms release phosphorus from sparingly soluble compounds and make it available to crop plants [12, 13]. Those microorganisms, known as phosphate-solubilizing bacteria (PSB), represent the following genera: Pseudomonas, Azotobacter, Bacillus, Rhizobium, Burkholderia and Enterobacter [14-16]. The aim of this study was to evaluate the phosphate solubilzation potential of non-agricultural Pseudomonas sp. SP-0113 and confirm its plant growth promotion properties on spring wheat.

\section{Material and Methods}

Pseudomonas sp. SP0113, the bacterial strain used in this study, was described in detail by Przemieniecki et al. [17] in 2015. Belonging to the species has been defined using API 20 NE (Biomerieux, France). The strain is capable of solubilizing mineral phosphorus and releasing phosphorus from organic compounds.

The solubilization of tricalcium phosphate (TCP, $\left.\mathrm{Ca}_{3}\left(\mathrm{PO}_{4}\right)_{2}\right)$ was determined based on changes in the $\mathrm{pH}$ of the NBRIP (National Botanical Research Institute's) phosphate growth medium, developed according to
Table 1. Parameters of the pot experiment.

\begin{tabular}{|c|c|}
\hline \multicolumn{2}{|c|}{ Soil properties } \\
\hline Textural class & $\begin{array}{c}\text { Loamy } \\
\text { sand }\end{array}$ \\
\hline $\mathrm{pH}(\mathrm{KCl})$ & 5.8 \\
\hline Total nitrogen $[\%]$ & 0.013 \\
\hline Phosphorus as $\mathrm{P}_{2} \mathrm{O}_{5}\left(\mathrm{mg} \mathrm{P} \cdot 100 \mathrm{~g}^{-1} \mathrm{soil}\right)$ & 24.5 \\
\hline Potassium as $\mathrm{K}_{2} \mathrm{O}\left(\mathrm{mg} \mathrm{K} \cdot 100 \mathrm{~g}^{-1} \mathrm{soil}\right)$ & 20.0 \\
\hline Magnesium $\left(\mathrm{mg} \mathrm{Mg} \cdot 100 \mathrm{~g}^{-1} \mathrm{soil}^{2}\right)$ & 4.5 \\
\hline Pre-sowing nitrogen fertilization $\left(\mathrm{mg} \mathrm{N}^{\mathrm{N}} \mathrm{kg}^{-1} \mathrm{soil}\right)$ & 125 \\
\hline Pre-sowing potassium fertilization $\left(\mathrm{mg} \mathrm{K}^{\mathrm{kg}} \mathrm{kg}^{-1}\right.$ soil $)$ & 125 \\
\hline Addition of $\mathrm{Ca}_{3}\left(\mathrm{PO}_{4}\right)_{2}\left(\mathrm{mg} \mathrm{P} \cdot \mathrm{kg}^{-1} \mathrm{soil}^{2}\right.$ & 25 \\
\hline
\end{tabular}

the method described by Nautiyal et al. [18] in 1999. The experiment was conducted in $250 \mathrm{ml}$ Schott bottles containing $99.9 \mathrm{ml}$ of the medium inoculated with $0.1 \mathrm{ml}$ of the overnight bacterial culture at a concentration of $1 \cdot 10^{9} \mathrm{CFU} \cdot \mathrm{ml}^{-1}$. The $\mathrm{pH}$ and redox potential of the medium were measured immediately after the addition of the bacterial strain and every $24 \mathrm{~h}$ for 5 days. The clarity (optical density measured at a wavelength of $600 \mathrm{~nm}-\mathrm{OD}_{600}$ ) of the solution was determined after sedimentation of the bacterial biomass and the coarse TCP fraction. Sedimentation time was determined based on the results of spectrophotometric tests.

The seed dressing solution was prepared by culturing bacteria on tryptic soy agar (TSA, Merck, Germany) at $27^{\circ} \mathrm{C}$ for $48 \mathrm{~h}$. After incubation, the culture was centrifuged (6000 rpm, $10 \mathrm{~min})$, suspended in sterile deionized water and concentrated to $5 \cdot 10^{8} \mathrm{CFU} \cdot \mathrm{ml}^{-1}$. The suspension was combined with sterile carboxymethyl cellulose (CMC, 1\% w/v) and silica. The kernel of spring wheat cv. Bombona was sterilized by rinsing in $50 \%$ ethanol for $1 \mathrm{~min}$, followed by $1 \%$ sodium hypochlorite for $10 \mathrm{~min}$. After sterilization, the kernel was rinsed three times in sterile distilled water and left to dry. Kernel was rinsed in a dressing solution, air dried and placed in soil at a depth of $2 \mathrm{~cm}$. The parameters of the pot experiment are presented in Table 1 .

All analyses were performed in three replications. The results were analyzed statistically in the Statistica 10 program with the use of t-student's test. After harvest, wheat plants were measured to determine the length of stems and spikes, spike weight, dry matter content, and kernel weight.

\section{Results and Discussion}

Based on the identification test we determined that the strain used in this study was most similar to Pseudomonas luteola. A preliminary analysis of the bacterial strain's growth potential on culture media 


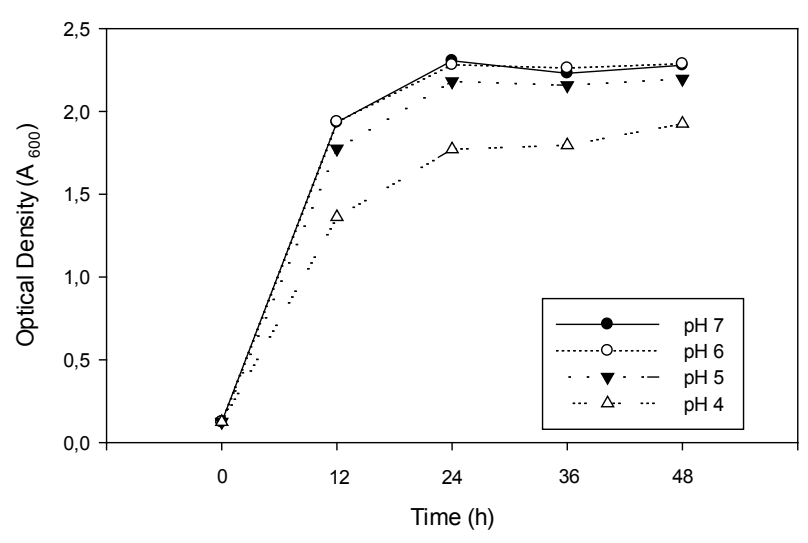

Fig. 1. Growth rate of Pseudomonas sp. SP0113 on culture media with different $\mathrm{pH}$.

with various $\mathrm{pH}$ revealed that Pseudomonas sp. SP0113 proliferated on all examined media. Bacterial concentrations were highest at $\mathrm{pH} 5-7$, whereas at $\mathrm{pH} 4$ bacterial growth was reduced by approximately $20 \%$ in the final log phase (after 24 h, Fig. 1).

The $\mathrm{pH}$ of the growth medium inoculated with Pseudomonas sp. SP0113 decreased relative to control, which indicates that bacterial metabolism led to the production of organic acids. During the 5-day incubation period, $\mathrm{pH}$ decreased by 2.4 , and the highest decrease of approximately 1 was noted between days 3 and 4 . The clarity of the solution containing TCP increased with a decrease in $\mathrm{pH}$, indicating that $\mathrm{Ca}_{3}\left(\mathrm{PO}_{4}\right)_{2}$ was transformed into a soluble compound (Figs 2-3). The highest loss of TCP was observed after $24 \mathrm{~h}$, and the solubilization process continued until day 5 , when $\mathrm{OD}_{600}$ reached the background value of 0.1 (Fig. 3).

In this study, the solubility of TCP indicates that Pseudomonas sp. SP0113 is capable of solubilizing

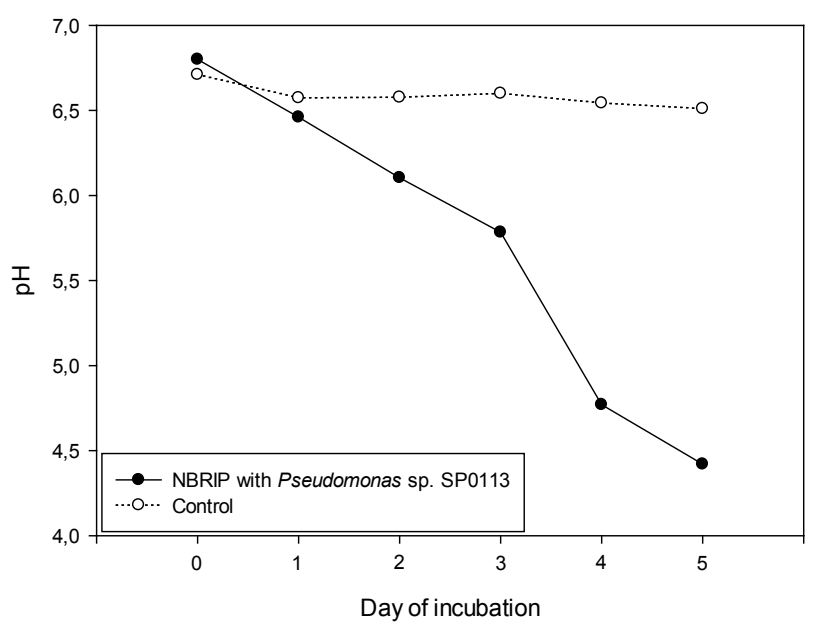

Fig. 2. Changes in the $\mathrm{pH}$ of the culture medium under the influence of the metabolites produced by Pseudomonas sp. SP0113.

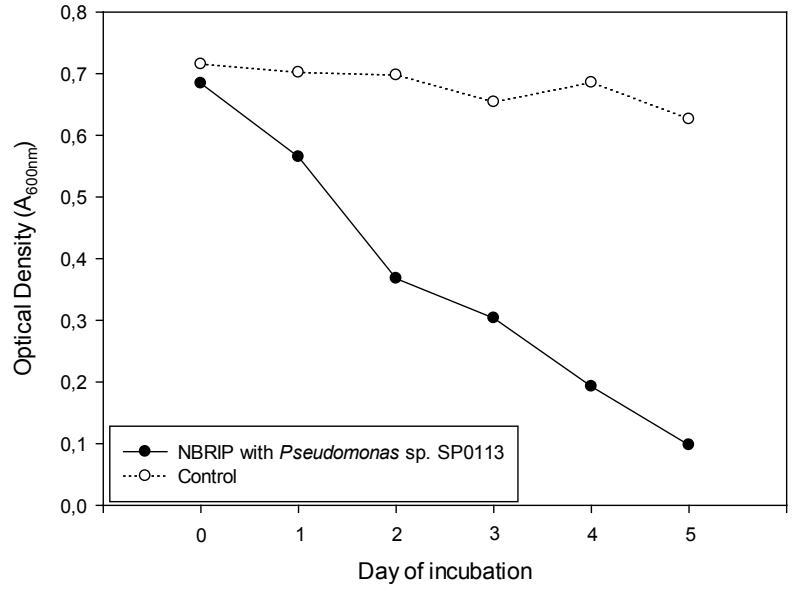

Fig. 3. Decrease in the turbidity of the NBRIP medium resulting from the solubilization of TCP $\left(\mathrm{Ca}_{3}\left(\mathrm{PO}_{4}\right)_{2}\right)$; medium clarity increased with a decrease in $\mathrm{A}_{600 \mathrm{~nm}}$ values.

phosphates. In the preliminary study, the P-solubilization index was high after 14 days of incubation on NBRIP agar [17]. In the liquid NBRIP medium, an absence of sparingly soluble phosphorus compounds was observed already after 5 days of incubation, which indicates that the analyzed bacteria can enhance plant growth in soils rich in phosphates (Fig. 3). Concentration of the organic acids in the NBRIP medium containing TCP was estimated at $20 \mu \mathrm{g} \mathrm{ml} \mathrm{m}^{-1}$.

Winter wheat kernel treated with the Pseudomonas sp. SP0113 strain was characterized by longer spikes than control; however, these results were not significantly different (Table 2).

The dry matter content of spikes was insignificantly higher in spring wheat whose kernel was not treated with the bacterial strain, which points to a higher percentage of chaff in the spike. Spring wheat whose kernel was dressed with Pseudomonas sp. SP0113 produced longer stems than control plants (Table 2). The yield of spring wheat inoculated with Pseudomonas sp. SP0113 was 7.5\% higher and thousand kernel weight was 5.6\% higher in comparison with control (Table 2). The thousand kernel weight of spring wheat inoculated with Pseudomonas sp. SP0113 was significantly higher in comparison with control (Table 2).

In the present study Pseudomonas sp. SP0113 was capable of solubilizing phosphates, which was confirmed by increasing the $\mathrm{pH}$ of medium and clarifying solutions with the insoluble fraction. Nevertheless, the first sign that the tested bacterial strain had the ability to dissolve inorganic phosporates was a selective medium test [17]. Similar results were reported by Park et al. [19], in whose study the Pseudomonas fluorescens RAF15 strain isolated from the ginseng rhizosphere led to a decrease in the $\mathrm{pH}$ of basal salt solution, similar to that induced by Pseudomonas sp. SP0113. In the above experiment, insoluble phosphorus was solubilized in the first 5 days, which is consistent with our findings. Thakker et al. [20] analyzed the growth-enhancing 
Table 2. Selected biometric parameters of spring wheat treated with the Pseudomonas sp. SP0113 strain as a dressing.

\begin{tabular}{|c|c|c|c|c|c|c|c|}
\hline Treatment & $\begin{array}{c}\text { Spike length } \\
(\mathrm{cm})\end{array}$ & $\begin{array}{c}\text { Spike weight } \\
\text { per pot }(\mathrm{g})\end{array}$ & $\begin{array}{c}\text { Spike dry mass } \\
\text { content }(\%)\end{array}$ & $\begin{array}{c}\text { Stem length } \\
(\mathrm{cm})\end{array}$ & $\begin{array}{c}1000 \text { kernel } \\
\text { weight }(\mathrm{g})\end{array}$ & $\begin{array}{c}\text { Increase } \\
\text { in kernel mass } \\
\text { relative } \\
\text { to control }(\%)\end{array}$ & $\begin{array}{c}\text { Increase } \\
\text { in kernel yield } \\
\text { relative } \\
\text { to control }(\%)\end{array}$ \\
\hline $\begin{array}{c}\text { Dressed } \\
\text { kernel }\end{array}$ & $7.17 \pm 0.53 \mathrm{~A}^{*}$ & $14.72 \pm 0.95$ & $88.62 \pm 0.24$ & $41.47 \pm 3.84$ & $36.35 \pm 0.52 \mathrm{~A}$ & 5.6 & 7.5 \\
\hline Control & $6.94 \pm 0.60 \mathrm{~B}$ & $14.20 \pm 1.23$ & $89.83 \pm 0.76$ & $40.76 \pm 6.36$ & $34.43 \pm 0.48 \mathrm{~B}$ & - & - \\
\hline
\end{tabular}

" The A and B letters accompanying the average mean the results differing from each other. Student's t-test was used in the statistical calculations.

potential of the Pseudomonas sp. OG strain isolated from seawater. The examined strain was also able to solubilize phosphates on Pikovskaya's broth. A medium inoculated with Pseudomonas sp. OG was characterized by slightly higher concentrations of solubilized phosphorus than the medium containing Pseudomonas RAF15. The growth-promoting effect of the analyzed strain was also observed in a greenhouse experiment.

Organic acids are the key factor responsible for P-solubilization by microorganisms. Their concentration in the NBRIP medium containing TCP was estimated at $20 \mu \mathrm{g} \mathrm{ml}^{-1}$. This value is typical of most bacteria of the genus Pseudomonas, which can produce more than 10 organic acids, where gluconic acid accounts for approximately $90 \%$ of total organic acids secreted into the medium [21, 22]. However, in some studies solvent effect had been assigned a different organic acid $[16$, 23].

In the present study the dry matter content of spikes was insignificantly higher in spring wheat whose kernel was not inoculated with the bacterial strain, which points to a higher percentage of chaff in the spike. In a study by Naiman et al. [24], the dry matter content of the aboveground parts of wheat plants inoculated with Azospirillum brasilense and Pseudomonas fluorescens strains was $20 \%$ higher. Rosas et al. [25] inoculated kernel with Pseudomonas aurantiaca SR1 and reported a higher dry matter content of stems in comparison with control. Positive influence on the yield of spring wheat after the inoculation of the kernel with the P. putida ART-9 was observed by Przemieniecki et al. [26].

Spring wheat kernel inoculated with Pseudomonas sp. SP0113 produced longer stems than control plants. This parameter varied considerably in control plants, which could adversely influence harvest. Zabihi et al. [27] and Kumar et al. [28] demonstrated that PGPB increases the height of wheat plants.

Kernel yield per unit area is influenced by different yield components, including the number of spikes, number of kernel per spike and thousand kernel weight. In the present study spring wheat dressed with Pseudomonas sp. SP0113 produced $7.5 \%$ higher yield and thousand kernel weight was $5.6 \%$ higher in comparison with control (Table 2). Similar results were reported by
Naiman et al. [24], Mäder et al. [29] and Kumar et al. [28]. In a study by Rosas et al. [25], inoculation with beneficial bacteria increased kernel yield. The cited authors demonstrated that the application of PGPB can produce kernel yields more than $30 \%$ higher than that noted in this study.

In this experiment, thousand kernel weight was the main yield-forming factor. Spring wheat inoculated with Pseudomonas sp. SP0113 had significantly higher thousand kernel weight in comparison with control (Table 2). In addition, this strain has a positive effect even under the pressure of herbicides (glyphosate) [30]. In a pot experiment by Shaharoona et al. [31], the thousand kernel weight of wheat treated with PGPB was $6-43 \%$ higher than in control.

\section{Conclusions}

The evaluated bacterial strain lowers $\mathrm{pH}$ in environments containing TCP $\left(\mathrm{Ca}_{3}\left(\mathrm{PO}_{4}\right)_{2}\right)$ and solubilizes phosphorus compounds unavailable to plant roots. Inoculation with the Pseudomonas sp. SP0113 bacterial strain improved the biometric parameters of spring wheat. The applied treatment did not exert a statistically significant effect on some parameters, but it increased kernel yield by $7.5 \%$ and thousand kernel weight by more than $5 \%$, indicating that the analyzed strain can be used as a dressing for spring wheat seeds. The test strain efficiently soluble phosphate under laboratory conditions and improves the yield of spring wheat. After optimizing technical properties, the potential use of a bacterial formulation as a bio-fertilizer is justified.

\section{Acknowledgements}

This work was financed by the Ministry of Science and Higher Education of Poland, research project No. 20.610.016-300.

\section{Conflict of Interest}

The authors declare no conflict of interest. 


\section{References}

1. KORZENIOWSKA J., STANISŁAWSKA-GŁUBIAK E. New trends in the use of phosphorites in agriculture. Post. Nauk Roln. 3, 57, 2011 [In Polish].

2. PARK S.H., SUNG J.K., LEE S.Y., JANG B.C., LEE B.H., KIM T.W. Early growth, carbohydrate, and phytic acid contents of germinating rice seeds under $\mathrm{NaCl}$ stress. Korean J. Crop Sci. 51, 137, 2006.

3. GAJ R., GRZEBISZ W. Phosphorus in the plant. In: Elements in the environment. Phosphorus. J. Elem., 8 (3, suppl), 5, 2003 [In Polish].

4. MOHAMMADI K. Phosphorus Solubilizing Bacteria: Occurrence, Mechanisms and Their Role in Crop Production. Resources and Environment, 2 (1), 80, 2012.

5. PANDE A., PANDEY P., MEHRA S., SINGH M., KAUSHIK S. Phenotypic and genotypic characterization of phosphate solubilizing bacteria and their efficiency on the growth of maize. Journal of Genetic Engineering and Biotechnology 15, 379, 2017.

6. POTARZYCKI J. Phosphorus in the soil. In: Elements in the environment. Phosphorus. J Elem.; 8 (3 suppl.), 19, 2003 [In Polish].

7. JONES D., OBURGER E. Solubilization of Phosphorus by Soil Microorganisms. In book: Phosphorus in Action: 169, 2011.

8. KHAN K.S., JOERGENSEN R.G. Changes in microbial biomass and $\mathrm{P}$ fractions in biogenic household waste compost amended with inorganic P fertilizers. Bioresour. Technol. 100, 303, 2009.

9. AFZAL A., BANO A. Rhizobium and phosphate solubilizing bacteria improve the yield and phosphorus uptake in wheat (Triticum aestivum L.). Int. J. Agri. Biol. 10, 85, 2008.

10. MOHAMMADI K., GHALAVAND A., AGHAALIKHANI M., HEIDARI G.R., SOHRABI Y. Introducing the sustainable soil fer-tility system for chickpea (Cicer arietinum L.). Afr J. Biotech. 10 (32), 6011, 2011.

11. ZAIDI A., KHAN M.S. Co-inoculation effects of phosphate solubilizing microorganisms and Glomus fascicu-latumon on green gram - Bradyrhizobium symbiosis. Turk. J. Agric. 30, 223, 2006.

12. RICHARDSON A.E. Prospects for using soil microorganisms to improve the acquisition of phosphorus by plants. Aust J Plant Physiol., 28, 8797, 2001.

13. PANDEY A., PALNI L.M.S., MULKALWAR P., NADEEM M. Effect of temperature on solubilization of tricalcium phosphate by Pseudomonas corrugata. J Sci Ind Res India, 61 (6), 457, 2002.

14. CHEN Y.P., REKHA P.D., ARUN A.B., SHEN F.T., LAI W.-A., YOUNG C.C. Phosphate solubilizing bacteria from subtropical soil and their tricalcium phosphate solubilizing abilities. Appl Soil Ecol., 34 (1), 33, 2006.

15. UMA MAHESWAR N., SATHIYAVANI G. Solubilization of phosphate by Bacillus Sps, from groundnut rhizosphere (Arachishypogaea L). J. Chem Pharm Res., 4 (8), 4007, 2012.

16. AHEMAD M., KIBRET M. Mechanisms and applications of plant growth promoting rhizobacteria: Current perspective. Journal of King Saud University - Science, 26 (1), 1, 2014.

17. PRZEMIENIECKI S.W., KUROWSKI T.P., KARWOWSKA A. Plant growth promoting potentials of Pseudomonas sp. SP0113 isolated from potable water from a closed water well. Arch Biol Sci., 67 (2), 663, 2015.
18. NAUTIYAL S.C. An efficient microbiological growth medium for screening phosphate solubilizing microorganisms. FEMS Microbiol Lett., 170, 265, 1999.

19. PARK K.H., LEE C.Y., SON H.J. Mechanism of insoluble phosphate solubilization by Pseudomonas fluorescens RAF15 isolated from ginseng rhizosphere and its plant growth-promoting activities. Lett Appl Microbiol., 49, 222, 2009.

20. THAKKER J.N., GOSWAMI D., VAGHELA H., PARMAR S., DHANDHUKIA P. Plant growth promoting potentials of Pseudomonas spp. strain OG isolated from marine water. J Plant Interact., 8 (4), 281, 2013.

21. PUENTE M.E., LI C.Y., BASHAN Y. Rock-degrading endophytic bacteria in cacti. Environ Exp Bot., 6, 389, 2009.

22. VYAS P, GULATI A. Organic acid production in vitro and plant growth promotion in maize under controlled environment by phosphate-solubilizing fluorescent Pseuodomonas. BMC Microbiol., 9, 10.1186/1471-2180-9174, 2009.

23. MIHALACHE G., ZAMFIRACHE M.-M., MIHASAN M., IVANOV I., STEFAN M., RAUS L. Phosphatesolubilizing bacteria associated with runner bean rhizosphere. Arch. Biol. Sci., 67 (3),793, 2015.

24. NAIMAN A.D., LATRONICO A., GARCIA DE SALAMONE I.E. Inoculation of wheat with Azospirillum brasilense and Pseudomonas fluorescens: Impact on the production and culturable rhizosphere microflora. Eur. J. Soil Biol., 45, 44, 2009.

25. ROSAS S.B., AVANZINI G., CARLIER E., PASLUOSTA C., PASTOR N., ROVERA M. Root colonization and growth promotion of wheat and maize by Pseudomonas aurantiaca SR1. Soil Biol. Biochem., 41, 1802, 2009.

26. PRZEMIENIECKI S.W., KUROWSKI T.P., KOTLARZ K., KRAWCZYK K., DAMSZEL M., KARWOWSKA A. Plant growth promoting properties of Serratia fonticola ART-8 and Pseudomonas putida ART-9 and their effect on the growth of spring wheat (Triticum aestivum L.). Environmental Biotechnology, 12 (2), 35, 2016.

27. ZABIHI H.R., SAVAGHEBI G.R., KHAVAZI K., GANJALI A., MIRANSARI M. Pseudomonas bacteria and phosphorous fertilization, affecting wheat (Triticum aestivum L.) yield and $\mathrm{P}$ uptake under greenhouse and field conditions. Acta Physiol. Plant., 33, 145, 2011.

28. KUMAR A., MAURYA B.R., RAGHUWANSHI R. Isolation and characterization of PGPR and their effect on growth, yield and nutrient content in wheat (Triticum aestivum L.). Biocatalysis and Agricultural Biotechnology, 3, 121, 2014.

29. MADER P., KAISER F., ADHOLEYA A., SINGH R., UPPAL H.S., SHARMA A.K., SRIVASTAVA R., SAHAI V., ARAGNO M, WIEMKEN A, JOHRI B.N., FRIED P.M. Inoculation of root microorganisms for sustainable wheat-rice and wheat-black gram rotations in India. Soil Biol. Biochem., 43, 609, 2011.

30. PRZEMIENIECKI S.W., KUROWSKI T.P., DAMSZEL M.M., KARWOWSKA A., ADAMIAK E. Effect of Roundup 360 SL on survival of Pseudomonas sp. SP0113 strain and effective control of phytopathogens. J. Agric. Sci. Technol. 19 (6), 1417, 2017.

31. SHAHAROONA B., JAMRO G.M., ZAHIR Z.A., ARSHAD M., MEMON K.S. Effectiveness of various Pseudomonas spp., and Burkholderia caryophylli containing ACC-deaminase for improving growth and yield (Triticum aestivum L.). Journal of Microbiology \& Biotechnology., 17, 1300-1307, 2007. 